\title{
EVALUATION OF THE REGULARITY OF ANTIHYPERTENSIVE DRUGS USAGE AS A COMPONENT OF TREATMENT ADHERENCE IN OUTPATIENTS OF A SPECIALIZED CARDIOLOGY CENTER
}

\author{
A.V. Kontsevaya1, T.S. Romanenko1*, V.A. Vygodin1, S.B. Fitilev² \\ 1 State Research Centre for Preventive Medicine. Petroverigsky per. 10, Moscow, 101990, Russia \\ 2 Peoples' Friendship University of Russia. Mikluho-Maklaya ul. 6, Moscow, 117198, Russia \\ High adherence to blood pressure (BP) medical correction determines clinical and socioeconomic efficacy of antihypertensive treatment. Separate components of adherence are to be stud- \\ ied, including regularity of drugs intake and reasons for non-compliance with medical recommendations in different categories of patients. \\ Aim. Evaluation of antihypertensive drugs (AHD) intake regularity (as a component of treatment adherence) and factors it is influenced by in hypertensive patients who had for the first time \\ visited a specialized cardiology center during the 6 -month follow-up after the primary consultation. \\ Material and methods. First, a number of hypertensive patients who had visited a cardiologist of one of Moscow's district cardiology clinics for the first time in 2010 ( $\mathrm{n}=1766$ ) had formed \\ a sample of the study participants. The expert cards were filled out in accordance with the primary medical documentation data. The second step was conducted 6 months after the first visit \\ by a phone survey with the completion of questionnaires ( $n=1419)$. \\ Results. Majority of respondents (74.9\%) had been taking AHD regularly 6 months after the primary consultation and $16.2 \%$ of the patients had been using them occasionally. $8.9 \%$ of the \\ respondents completely refused to control hypertension with drugs. Respondents of male sex $(\mathrm{OR}=1.4)$, with poor $\mathrm{BP}$ self-control in home settings (OR=2.5), unable to get drugs under the \\ medicine assistance scheme $(O R=1.8)$, those without coronary heart disease $(O R=1.9)$, with hypertension duration less than 5 years $(O R=1.9)$, with changes in antihypertensive therapy \\ regimen as compared to the one recommended by a cardiologist $(O R=1.5)$, those who had $1-2$ drugs in the treatment regimen at the moment of the survey $(O R=2.4)$ and patients who had \\ no fixed drug combinations in the treatment scheme $(O R=1.4)$ were shown to have significantly higher probability of irregular AHD intake or complete treatment refusal. \\ Conclusion. Outpatients of the specialized cardiology center are characterized by rather high treatment adherence by AHD intake regularity. We have revealed a number of factors that sig- \\ nificantly correlate with reduced antihypertensive treatment adherence. These factors must be taken into account at treatment regimen selection and patients' follow-up. \\ Key words: hypertension; outpatients; treatment adherence; regular drugs intake \\ Ration Pharmacother Cardiol 2015;11(3):238-246
}

Анализ регулярности приема антигипертензивной терапии как компонента приверженности лечению у амбулаторных пациентов специализированного кардиологического учреждения

А.В. Концевая 1 , Т.С. Романенко ${ }^{*}$, В.А. Выгодин1', С.Б. Фитилев²

1Государственный научно-исследовательский центр профилактической медицины. 101990, Москва, Петроверигский пер., 10

2Российский университет дружбы народов. 117198, Москва, Миклухо-Маклая ул., 6

Высокая приверженность медикаментозной коррекции артериального давления (АД) определяет клиническую и социально-экономическую эффективность лечения артериальной гипертензии (АГ). Необходимо изучение отдельных компонентов приверженности, включая регулярность приема препаратов, и причин несоблюдения врачебных рекомендаций у различных категорий пациентов.

Цель. Изучить регулярность приема антигипертензивных препаратов (АГП) как компонента приверженности лечению, а также факторов, влияющих на нее, среди пациентов с АГ, впервые обратившихся в специализированное кардиологическое учреждение, в течение 6 мес после первичной консультации.

Материал и методы. На первом этапе была сформирована выборка из числа пациентов с АГ, в 2010 г. впервые обратившихся к кардиологу одного из окружных кардиодиспансеров г. Москвы (n=1766). По данным первичной медицинской документации пациентов заполнены экспертные карты. На втором этапе проведен телефонный опрос через 6 мес после первичного приема с заполнением опросников $(n=1419)$.

Результаты. Через 6 мес после первичной консультации АГП регулярно принимало большинство опрошенных (74,9\%), периодически - 16,2\% пациентов. Полностью отказались от медикаментозного контроля АГ 8,9\% респондентов. Значимо более высокий шанс нерегулярного приема АГП или отказа от них вообще установлен у респондентов мужского пола (ОШ=1,4), снизким уровнем самоконтроля АД в домашних условиях (ОШ=2,5), не имеющих возможности получения препаратов в рамках дополнительного льготного обеспечения (ОШ=1,8), с отсутствием ишемической болезни сердца (ОШ=1,9), стажем АГ до 5 лет (ОШ=1,9), имеющих в схеме лечения на момент опроса 1-2 препарата $($ ОШ=2,4), с наличием изменений схемы лечения АГ по сравнению с рекомендованной кардиологом $($ ОШ=1,5), а также не имеющих в схеме лечения фиксированных комбинаций (ОШ=1,4).

Заключение. Амбулаторные пациенты специализированного кардиологического учреждения характеризуются достаточно высокой приверженностью лечению по показателю регулярности приема АГП. Выявлен ряд факторов, значимо связанных с уменьшением приверженности лечению АГ, которые следует учитывать при назначении схем лечения и динамическом наблюдении за пациентами

Ключевые слова: артериальная гипертензия, амбулаторные пациенты, приверженность лечению, регулярный прием препаратов

Рациональная фармакотерапия в кардиологии 2015;11(3):238-246

*Corresponding author (Автор, ответственный за переписку): RomanenkoTD@yandex.ru

Significant negative social and economic consequences of inadequate arterial hypertension control demand special measures focused on improving the situation. The key factor in improving hypertension treatment efficacy is treatment adherence, which is always a problem in case of a long-term

\footnotetext{
Author's information:

Anna V. Kontsevaya - MD, PhD, Head of Laboratory of Economic Analysis of Epidemiologic Studies and Preventive Programs, Department of Epidemiology of Chronic Non-infectious Diseases, State Research Centre for Preventive Medicine (SRC PM)

Tatyana S. Romanenko - MD, Degree Seeking Applicant of the Department of Epidemiology of Chronic Non-infectious Diseases, SRC PM Vladimir A. Vygodin - Senior Researcher of Laboratory of Biostatistics, SRC PM

Sergey B. Fitilev - MD, PhD, Professor of the General and Clinical Pharmacology Chair, Peoples' Friendship University of Russia
}

Значительные негативные социально-экономические последствия неадекватного контроля артериальной гипертонии (АГ) для общества требуют специальных мер, направленных на улучшение ситуации. Ключевой фактор повышения эффективности лечения АГ - это приверженность к лечению, которая всегда является проблемой в случае дли-

\footnotetext{
Сведения об авторах:

Концевая Анна Васильевна - д.м.Н., руководитель лаборатории экономического анализа эпидемиологических исследований и профилактических технологий отдела эпидемиологии хронических неинфекционных заболеваний ГНИЦ ПМ
}

Романенко Татьяна Сергеевна - соискатель того же отдела Выгодин Владимир Анатольевич - С.н.С. лаборатории биостатистики того же отдела

Фитилев Сергей Борисович - д.м.Н., профессор кафедры общей и клинической фармакологии РуДН 
drugs intake [1]. Improvement in antihypertensive treatment adherence has been demonstrated to reduce blood pressure (BP) significantly [2], which consequently lowers the risk of target-organs damage and cardiovascular complications [3,4] and promotes the reduction in health care system resources expenditures [5].

The analysis of hypertension epidemiological situation in Russia during 2003-2013 years has revealed no significant positive dynamics both in the coverage of patients with antihypertensive treatment and in hypertension control $[6,7]$. Incidence rate of antihypertensive drugs (AHD) intake in the Russian population during the 2003-2010 years, which was estimated within the program of hypertension monitoring, was from $62.6 \%$ to $66.1 \%$ in hypertensive patients [6]. According to the further ESSE research (2012-2013 years) treatment coverage was only $50.5 \%$ [7]. The PIFAGOR study has revealed that in real clinical practice the share of outpatients in Russia continuously using AHD has increased by nearly 17\% from 2002 to 2008 year and has eventually achieved 79\% [8]. In our study of outpatients of a cardiology center high incidence rate (91\%) of AHD intake prescribed in accordance with the contemporary guidelines, has$n$ 't shown high efficacy of hypertension control: we have revealed low incidence of target blood pressure achievement and high incidence of hypertensive crises [9]. This testifies to the necessity of treatment adherence evaluation as an important part of patients' management, including it's such components as drugs intake regularity and keeping up with the recommended treatment regimen [10] with the analysis of reasons for non-compliance. Besides, at the present day, there are no Russian studies evaluating antihypertensive therapy adherence in terms of medical help succession, i.e. out-patient follow-up by general practitioner after the consultation of a cardiologist. Such trials can become a framework for the development of measures to increase patients' compliance with the prescribed treatment, including the use of modern technologies [11]

The aim of the study was to evaluate the regularity of AHD use (as one of the components of treatment adherence) and factors it is influenced by in hypertensive patients who had for the first time visited a specialized cardiology center during the 6 -month follow-up after the primary consultation.

\section{Material and methods}

The study design was described earlier in detail [9]. The study comprised two steps. The first step took тельного приема препаратов [1]. Установлено, что повышение приверженности к антигипертензивной терапии (АГТ) способствует существенному снижению артериального давления (АД) [2], и, соответственно, сокращает риск развития поражения органов-мишеней [3] и ее сердечно-сосудистых осложнений [4], а также способствует сокращению расходования ресурсов системы здравоохранения [5].

Анализ эпидемиологической ситуации в отношении АГ в России на протяжении 2003-2013 гг. свидетельствует об отсутствии существенной положительной динамики охвата лечением пациентов и контроля АГ $[6,7]$. Частота приема антигипертензивных препаратов (АГП) в российской популяции в периоды 2003-2010 гг, оценка которой проводилась в рамках программы мониторинга АГ, составила от $62,6 \%$ до 66, $1 \%$ среди лиц с повышенным АД [6]. По данным более позднего популяционного исследования ЭССЕ, проведенного в 2012-2013 гг., выявлено, что охват лечением составил всего 50,5\% [7]. По данным исследования ПИФАГОР в реальной клинической практике доля российских амбулаторных пациентов, постоянно принимающих АГП, с 2002 по 2008 гг. увеличилась почти на 17\%, в итоге достигнув 79\% [8]. В проведенном нами исследовании амбулаторных пациентов кардиологического диспансера высокий охват лечением (91\%), назначаемым в соответствии с современными рекомендациями, не приводил к высокой эффективности контроля АГ (выявлена низкая частота достижения целевого АД и высокая частота гипертонических кризов) [9]. Это свидетельствует о необходимости оценки приверженности пациента как важной части лечения, в том числе отдельных ее компонентов, таких, как регулярность приема препаратов и соблюдение рекомендованной схемы лечения [10], включая анализ причин несоблюдения врачебных рекомендаций. Кроме того, в настоящее время в России отсутствуют исследования, в которых была бы проведена оценка приверженности к АГТ с точки зрения преемственности оказания медицинской помощи, т.е. после консультации специалиста-кардиолога при дальнейшем амбулаторном наблюдении пациента врачом-терапевтом. Подобные работы могут стать основной для разработки мер по повышению соблюдения пациентами назначенного лечения, в том числе с использованием современных технологий [1 1].

Целью исследования являлось изучение регулярности приема АГП (как компонента приверженности к лечению) и факторов, влияющих на нее, среди пациентов с АГ, впервые обратившихся в специализированное кардиологическое учреждение, в течение 6 мес после первичной консультации.

\section{Материал и методы}

Дизайн исследования детально описан ранее [9]. Исследование включало два этапа. На первом этапе на базе одного из окружных кардиодиспансеров Москвы из числа пациентов с АГ, впервые обратившихся в 2010 г. (с января по декабрь) к врачу-кардиологу, была сформирована вы- 
place in one of Moscow's district cardiology clinics. A number of hypertensive patients who had visited a cardiologist of the clinic for the first time in 2010 (from January till December) had formed a primary sample of the study participants with further completion of the expert cards in accordance with the primary medical documentation data $(n=1766)$. The patients could have been earlier followed up in local outpatient clinics of Moscow. Outpatient cards data were copied on certain days of the week from June of 2010 till April of 2011. The study included all hypertensive patients who had visited the cardiology center for the first time and whose primary medical documents were available.

The second step was conducted 6 months after the first visit to a cardiologist by a phone survey. A total number of respondents was 1419 (80.4\% of the primary sample).

Regularity of AHD intake by the study participants was analyzed as a component of antihypertensive treatment adherence. Treatment regularity was evaluated by the respective question in the inquiry form. The fact of daily intake of the recommended drugs was regarded as a treatment regularity criterion. All the patients were divided into two groups: the group 1 - patients who received antihypertensive drugs regularly, the group 2 - those who used the drugs irregularly or refused medical treatment.

Antihypertensive therapy included the following drug classes: angiotensin converting enzyme inhibitors, $\beta$-blockers, calcium antagonists, angiotensin II receptor blockers, drugs with central mode of action, renin inhibitors and drugs with multiple mechanism of action ("Adelphane", "Andipal").

Statistical analysis was performed on the basis of standard algorithms of variation statistics by the software package SAS (Statistical Analysis System, SAS Institute Inc., the USA). In particular, odds ratio (OR) with the calculation of $95 \%$ confidence interval $(\mathrm{Cl})$ was estimated at the analysis of relative risk for the association of different factors with the irregular AHD intake or treatment refusal.

\section{Results and discussion}

Sociodemographic and clinical characteristics of the study participants were presented earlier [9]. Majority of the study participants were women (68.6\%). Mean hypertension duration was $11.56 \pm 0.26$ years. According to the examination data most of the patients had high and very high cardiovascular risk (initially $-27.4 \%$ and $66.7 \%$, respectively). Patients of the cardiology center revealed significant number of concomitant diseases, primarily cardiovascular ones. борка участников исследования с последующим заполнением экспертных карт по данным первичной медицинской документации ( $n=1766)$. Пациенты могли ранее наблюдаться по поводу АГ в территориальных поликлиниках г. Москвы. Выкопировка данных из амбулаторных карт производилась в определенные дни недели (1-2 дня) в период с июля 2010 г. по апрель 2011 г. В исследование включались все пациенты, впервые обратившиеся с АГ в кардиодиспансер, первичная медицинская документация которых была доступна в регистратуре данного лечебного учреждения.

Второй этап проводился через 6 мес после первичного приема кардиолога кардиодиспансера методом телефонного опроса. Общее число опрошенных составило 1419 человек (отклик 80,4\% от первоначальной выборки).

В качестве компонента приверженности к АГТ анализировали регулярность приема АГП участниками исследования. Регулярность лечения оценивали на основании вопроса анкеты. В качестве критерия регулярности лечения принят факт ежедневного приема рекомендованных препаратов. Все пациенты были разделены на две группы: 1 группа - регулярно принимающие АГП, и 2 группа - нерегулярно принимающие препараты или вообще отказавшиеся от терапии.

К АГТ были отнесены следующие фармакологические классы препаратов: ингибиторы ангиотензинпревращающего фермента, $\beta$-адреноблокаторы, антагонисты кальция, блокаторы рецепторов к ангиотензину II, препараты с центральным механизмом действия, ингибиторы ренина и препараты с множественным механизмом действия («Адельфан», «Андипал»).

Статистическая обработка результатов выполнялась на основе стандартных алгоритмов вариационной статистики с использованием статистического пакета SAS (Statistical Analysis System, SAS Institute Inc., СШA). В частности, при анализе относительного риска для ассоциации различных факторов с нерегулярным приемом АГТ или отказом от терапии были рассчитаны соответствующие отношения шансов (ОШ) с вычислением 95\% доверительного интервала (ДИ).

\section{Результаты и обсуждение}

Социально-демографическая и клиническая характеристика участников исследования представлена нами ранее [9]. Большинство участников исследования были женского пола (68,6\%). Средняя длительность АГ составила $11,56 \pm 0,26$ лет. По результатам обследования установлено, что в абсолютном большинстве случаев у пациентов наблюдался высокий и очень высокий риск развития сердечнососудистых осложнений АГ ( исходно у 27,4\% и 66,7\%, соответственно). Пациенты кардиодиспансера характеризовались значительным числом сопутствующих заболеваний, прежде всего сердечно-сосудистых. Так, ишемическая болезнь сердца (ИБС) встречалась в 51,6\% случаев на первом этапе исследования. 
So, $51.6 \%$ of the patients had coronary heart disease (CHD) at the first step of the study.

At evaluation of antihypertensive treatment regularity it was found out that the majority of outpatients of the specialized cardiology center received AHD during the 6-month follow-up regularly (74.9\%), $16.2 \%$ of the patients used the drugs occasionally, while $8.9 \%$ of the respondents completely refused antihypertensive medical treatment. The share of the patients regularly receiving antihypertensive treatment was comparable with the results of the multicenter PIFAGOR III study (79\%) [8], however, this trial had mainly included patients of primary health care system.

Patients newly diagnosed with hypertension refused antihypertensive treatment in $20.3 \%$ of the cases during the first 6 months after the therapy prescription [12]. In our study the incidence rate of treatment refusals was lower, probably due to a longer duration of hypertension in our patients and a larger number of cardiovascular comorbidities.

The Figure 1 displays main reasons for irregular AHD intake in patients who did not follow the recommended treatment regimen 6 months after the primary consultation.

The feeling of well-doing was found out to be the main reason for irregular AHD intake (73\%). This indicates low health literacy of the patients, who, despite long duration of the disease and follow-up in
При оценке регулярности приема АГП показано, что большинство амбулаторных пациентов специализированного кардиологического учреждения в течение 6 мес регулярно принимали АГ (74,9\%), еще 16,2\% периодически принимали АГТ, а 8,9\% опрошенных полностью отказались от медикаментозного контроля АГ. Доля пациентов, постоянно принимающих АГТ, сопоставима с результатами многоцентрового исследования ПИФАГОР ІІІ в реальной клинической практике (79\%) [8], однако в этом исследовании преимущественно были пациенты первичного звена здравоохранения.

У пациентов с впервые диагностированной АГ отказ от АГТ в течение первых 6 мес после назначения лечения наблюдается в 20,3\% случаев [12]. В нашем исследовании частота отказа от лечения была ниже, вероятно, в связи с тем, что это были пациенты с большим стажем АГ и большим числом сердечно-сосудистых заболеваний.

На рис. 1 представлены основные причины нерегулярного приема АГТ у тех пациентов, которые через 6 мес после первичной консультации не принимали препараты регулярно в соответствии с рекомендованной врачом схемой.

Наиболее значимой причиной нерегулярного приема АГП оказалось хорошее самочувствие пациентов (73\%). Это является показателем низкой медицинской грамотности пациентов, которые, несмотря на наличие значительного стажа заболевания и наблюдение в специализированном кардиологическом учреждении, не понимают целей лечения АГ и недостаточно осведомлены о последствиях неэффективного контроля АГ. Таким образом, консультация кар-

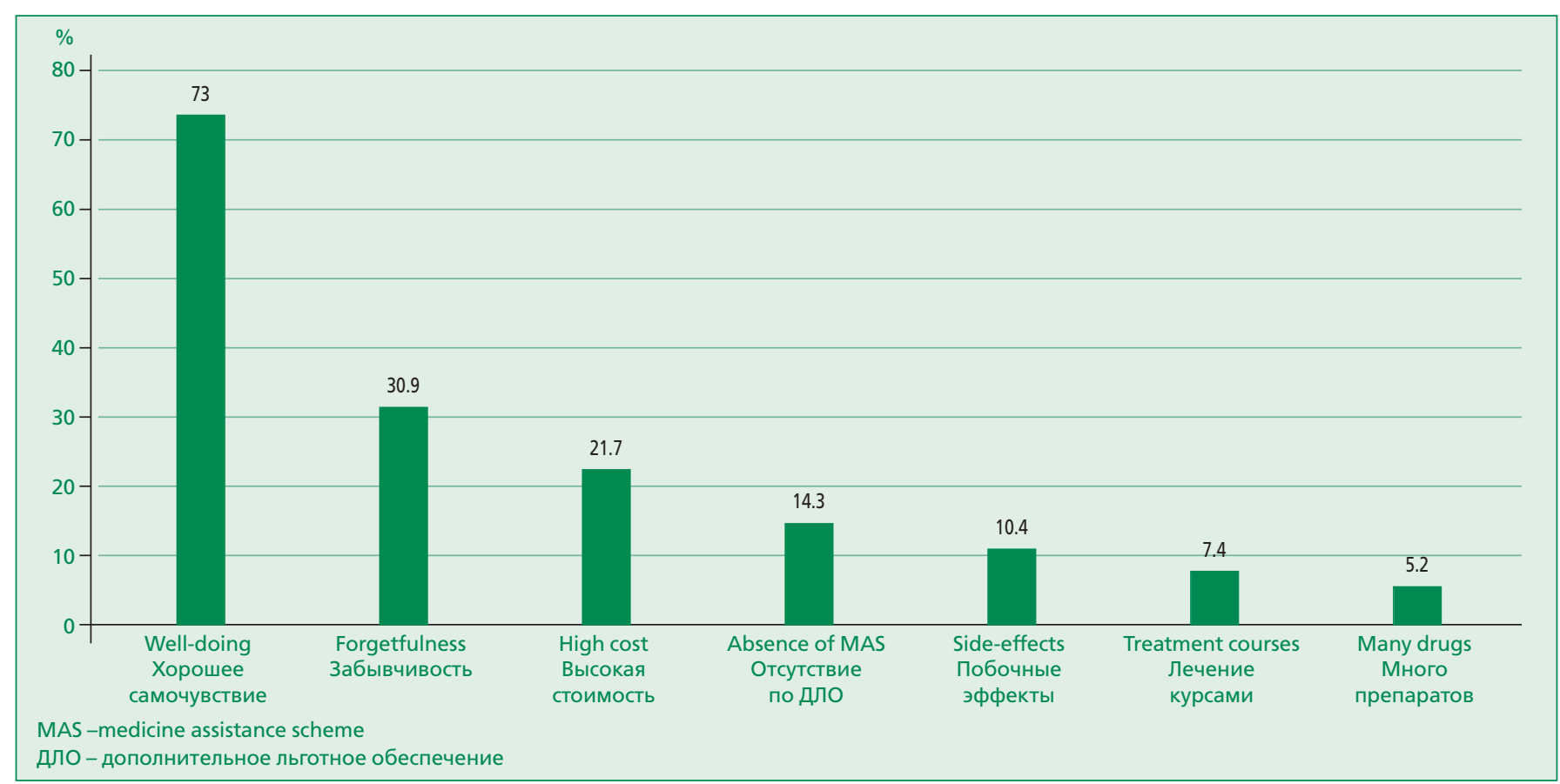

Figure 1. Main reasons for irregular antihypertensive drugs intake by the patients of the cardiology center 6 months after the primary consultation

Рисунок 1. Основные причины нерегулярного приема АГТ пациентами кардиодиспансера через 6 мес после первичной консультации 
the specialized cardiology center, do not understand goals of antihypertensive treatment and are insufficiently aware of consequences of ineffective hypertension control. So, a consultation of a cardiologist of the cardiology center without special measures aimed at increasing treatment adherence, do not motivate patients to regular treatment and do not improve patients' health literacy.

Treatment adherence is a complex phenomenon that demands special technologies for its improvement.

Forgetfulness was also an important cause of irregular drugs intake: every third patient indicated it as a cause of irregular antihypertensive treatment (30.9\%), which is an indirect indicator of insufficient doctor-patient communication. The GARANT study has also demonstrated the feeling of well-being and forgetfulness to be the leading causes of irregular antihypertensive treatment $(38.6 \%$ and $35.8 \%$, respectively) [13]. These two leading reasons for irregular treatment can be overcome on the condition that sufficient doctor-patient communication is provided. At the present day a number of approaches have been developed to increase treatment adherence $[14,15]$.

High cost of the drugs wasn't a significant reason for irregular antihypertensive treatment in patients of the cardiology center ( $21.7 \%)$, despite the fact that a large part of the study participants were retired people. This testifies to the fact that the majority of patients either receive necessary medications by the medicine assistance scheme (MAS) or capable of acquiring them by themselves without significant pecuniary difficulties (there are a lot of generics on the market). The absence of drugs in the list of the MAS was the reason for regular treatment refusal in $14.3 \%$ of the cases and the side effects - in $10.4 \%$. So, objective reasons such as difficulties in getting drugs by the MAS and side-effects were the causes of irregular drugs intake in a small share of patients, while the majority of patients refused regular drugs intake for controllable reasons, which can be eliminated at focused doctor-patient communication.

The Figure 2 presents the incidence rate of target BP achievement as an indicator of hypertension treatment efficacy in groups of patients with different regularity of AHD intake.

As the Figure 2 shows AHD intake regularity was associated with hypertension treatment efficacy. A share of patients with the achieved target BP level was significantly lower in the group of patients who received AHD occasionally or did not receive them at диолога кардиодиспансера без применения специальных мер по повышению приверженности к терапии не сопровождается повышением мотивации пациентов к регулярной терапии за счет увеличения грамотности пациентов. Приверженность к лечению - это сложное явление, для позитивного влияния на которое необходимы специальные технологии.

Значимой причиной нерегулярного приема препаратов также оказалась забывчивость: каждый третий пациент отметил эту причину нерегулярного приема АГП (30,9\%), что является косвенным признаком недостаточной работы с пациентами. В исследовании ГАРАНТ две ведущие причины нерегулярного приема АГП оказались аналогичными: хорошее самочувствие $(38,6 \%)$ и забывчивость $(35,8 \%)$ [13]. Две самые частые причины нерегулярной АГТ преодолимы при условии достаточного внимания со стороны врача и работы с пациентом. В настоящее время разработан ряд методик, позволяющих повысить приверженность к лечению $[14,15]$

Высокая стоимость препаратов оказалась не столь значи мой причиной нерегулярного приема АГП пациентами кардиодиспансера $(21,7 \%)$ несмотря на то, что участники исследования в значительной части случаев были пенсионерами. Это свидетельствует о том, что большинство пациентов либо получают необходимые препараты по программе дополнительного льготного обеспечения (ДЛО), либо способны приобрести их сами без существенного ущерба для бюджета (на рынке имеется большое количество дженериков)

Отсутствие препаратов в списке ДЛО явилось причиной отказа от регулярного приема препаратов в 14,3\%, а побочные эффекты - в 10,4\%. Таким образом, объективные причины отказа от регулярного приема АГП, такие, как сложность получения препаратов по ДЛО и побочные эффекты, явились причиной нерегулярного приема препаратов лишь у небольшой доли пациентов, а основная доля пациентов отказывается от регулярного приема медикаментов по управляемым причинам, которые можно устранить при целенаправленной работе с пациентами.

На рис. 2 представлена частота достижения целевого АД как показателя эффективности лечения АГ в группах пациентов с различной регулярностью приема АГП.

Как видно из рис. 2 регулярность приема АГТ ассоции рована с эффективностью лечения АГ. В группе пациентов, периодически принимающих АГТ или не принимающих АГТ вообще, доля пациентов с достигнутым целевым АД оказалась значимо ниже по сравнению с пациентами, указавшими на регулярный прием АГП ( $p<0,001)$.

В табл. 1 представлены ассоциации различных факторов с вероятностью низкой приверженности к лечению, оцененной по критерию регулярности приема препаратов.

Ассоциации регулярности приема АГП с возрастом не выявлено, поэтому стандартизация по возрасту проведена не была.

Среди факторов, связанных с нерегулярным приемом пациентом АГП, значимо ассоциировались мужской пол 
all as compared with those who received regular treatment $(p<0.001)$.

Associations of different factors with the probability of low treatment adherence estimated by the criterion of drugs intake regularity are listed in the Table 1.

We have not revealed association of AHD intake regularity with age, so, no age adjustment has been performed.

Such factors as male sex and the absence of BP self-control were significantly associated with irregular drugs intake $(\mathrm{OR}=1.43 ; 95 \% \mathrm{Cl}$ from 1.11 to $1.842 ; p<0.01$ and $O R=2.472 ; 95 \% \mathrm{Cl}$ from 1.867 to $3.274 ; p<0.001$, respectively). Association of male sex with poor antihypertensive treatment adherence has already been demonstrated earlier $[16,17]$. The absence of BP self-control is a marker of low compliance with recommendations in general, that is why such patients need additional consideration. This association is also the established fact [17].

The absence of possibility to get drugs by the MAS was expectedly associated with irregular AHD intake $(\mathrm{OR}=1.831 ; 95 \% \mathrm{Cl}$ from 1.43 to $2.346 ; \mathrm{p}<0.001)$. For many patients receiving drugs by the MAS system is a factor that increases treatment adherence, because in this case they don't need to spend their own funds. One of national trials has demonstrated direct correlation between increased medical reimbursement and patients adherence to antihypertensive treatment [18]. On the other hand, patients did not indicate high drug prices as a significant reason for irregular drugs intake, so, apparently it matters only for a part of patients.

Among the factors associated with the disease, CHD absence was related to the increased possibility of irregular AHD intake (OR=1.945; $95 \%$ Cl from 1.522 to $2.485 ; p<0.001)$, as well as short hypertension duration (up to 5 years: $\mathrm{OR}=1.949 ; 95 \% \mathrm{Cl}$ from 1.494 to 2.544 ; $\mathrm{p}<0.001)$. The relationship between treatment adherence and concomitant cardiovascular diseases has been demonstrated earlier $[19,20]$, including a trial conducted in specialized cardiology centers [21]. As for hypertension duration literature data are questionable. In a study carried out in a specialized cardiology center a group of highly adherent patients had significantly shorter duration of hypertension than a group of patients with poor adherence [21]. Some other national trials had demonstrated association of longer hypertension duration with the increased treatment adherence $[18,20]$. At that, the presence of hypertensive crises was not associated with the irregular antihypertensive treatment.

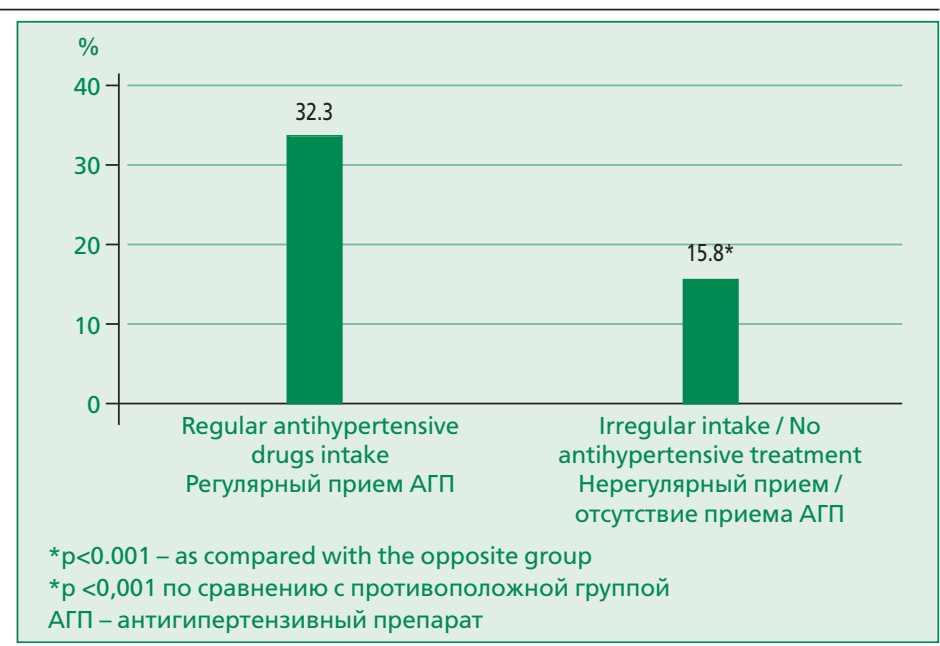

Figure 2. The incidence rate of target BP achievement in the examined groups

Рисунок 2. Частота достижения целевого

АД в изучаемых группах

(ОШ=1,43; $95 \%$ ДИ от 1,11 до 1,842; р<0,01) и отсутствие самоконтроля АД (ОШ=2,472; $95 \%$ ДИ от 1,867 до 3,274; $\mathrm{p}<0,001)$. Ассоциация мужского пола с низкой приверженностью к АГТ ранее уже была продемонстрирована $[16,17]$. А отсутствие самоконтроля АД является маркером низкой приверженности к выполнению рекомендаций в целом, поэтому такие пациенты нуждаются в дополнительном внимании. Эта ассоциация также является установленным фактом [17].

Отсутствие возможности приобретения лекарств по ДЛО ожидаемо ассоциировалось с нерегулярным приемом АГП (ОШ=1,831; $95 \%$ ДИ от 1,43 до 2,346; $p<0,001)$. Получение препаратов посредством системы ДЛО для многих пациентов является фактором, повышающим приверженность к лечению, так как в этом случае не требуется расходования собственных средств. В исследовании отечественных авторов установлена прямая взаимосвязь между увеличением льготного обеспечения пациентов и приверженностью к АГТ [18]. С другой стороны, высокая стоимость препаратов не была названа самими пациентами как значимая причина нерегулярного приема АГП, так что, по-видимому, она имеет значение лишь для части пациентов.

Среди факторов, ассоциированных с заболеванием, отсутствие ИБС ассоциировалось с увеличением вероятности нерегулярного приема АГП (ОШ=1,945; 95\% ДИ от 1,522 до 2,485; $p<0,001$ ), так же, как и небольшой стаж АГ (до 5 лет: ОШ=1,949; 95\% ДИ от 1,494 до 2,544; $p<0,001)$. Ассоциация приверженности с сопутствующими сердечно-сосудистыми заболеваниями продемонстрирована ранее $[19,20]$, в том числе в исследовании, проведенном в специализированных кардиологических учреждениях [21]. В отношении стажа АГ данные литературы являются неоднозначными. В исследовании, проведенном в специализированном кардиологическом учреждении, группа пациентов с высокой приверженностью характеризовалась значимо меньшей длительностью АГ по сравнению с 
Table 1. Association of sociodemographic, clinical factors and peculiarities of cardiovascular treatment with the probability of irregular antihypertensive drugs intake or treatment refusal

Таблица 1. Ассоциация социально-демографических, клинических факторов, характеристик сердечно-сосудистой терапии с вероятностью нерегулярного приема АГП или отказа от терапии

\begin{tabular}{|c|c|c|c|c|}
\hline Parameter / Параметр & $\begin{array}{r}\text { I } \\
\text { tre } \\
\text { Перv } \\
\text { от }\end{array}$ & $\begin{array}{l}\text { yular intake / } \\
\text { nent refusal, \% } \\
\text { ический прием/ } \\
\text { от лечения, \% }\end{array}$ & $\begin{array}{l}\text { OR (95\% Cl) } \\
\text { ОШ (95\% дИ) }\end{array}$ & $\mathrm{p}$ \\
\hline \multicolumn{5}{|c|}{ Factors related to the patient / Факторы, связанные с пациентом } \\
\hline \multirow[t]{2}{*}{ Sех / Пол } & Men / Мужчины & 29.9 & $1.43(1.11-1.842)$ & \multirow[t]{2}{*}{$<0.01$} \\
\hline & Women / Женщины & 23.0 & 1.000 & \\
\hline \multirow[t]{2}{*}{ Age / Возраст } & Under 60 years / До 60 лет & 27.8 & $1.272(0.997-1.621)$ & \multirow[t]{2}{*}{$>0.05$} \\
\hline & 60 years and older / 60 лет и старше & 23.3 & 1.000 & \\
\hline \multirow[t]{2}{*}{$\begin{array}{l}\text { Regularity of BP self-control / } \\
\text { Регулярность самоконтроля АД }\end{array}$} & $\begin{array}{l}\text { Does not measure BP/measures when } \\
\text { feeling unwell / Не измеряет АД/ } \\
\text { измеряет при ухудшении самочувствия }\end{array}$ & 40.4 & $2.472(1.867-3.274)$ & \multirow[t]{2}{*}{$<0.001$} \\
\hline & $\begin{array}{l}\text { Occasionally or regularly measures BP } \\
\text { Периодически измеряет АД/регулярно } \\
\text { измеряет АД }\end{array}$ & 21.5 & 1.000 & \\
\hline \multicolumn{5}{|c|}{ Factors related to the organization of health care system / Факторы, связанные с организацией системы здравоохранения } \\
\hline Possibility of the MAS use & Yes / Да & 19.1 & 1.000 & \multirow[t]{2}{*}{$<0.001$} \\
\hline Возможность использования ДЛО & № / Нет & 30.2 & $1.831(1.43-2.346)$ & \\
\hline \multicolumn{5}{|c|}{ Factors related to cardiovascular diseases / Факторы, связанные с сердечно-сосудистыми заболеваниями } \\
\hline CHD presence & Yes / Ecrb & 19.3 & 1.000 & \multirow[t]{2}{*}{$<0.001$} \\
\hline Наличие ИБС & № / Нет & 31.7 & $1.945(1.522-2.485)$ & \\
\hline Hypertension duration & Less than 5 years (including) / До 5 лет (включит.) & 31.3 & $1.949(1.494-2.544)$ & \multirow[t]{2}{*}{$<0.001$} \\
\hline Стаж АГ & More than 5 years / Более 5 лет & 19.0 & 1.000 & \\
\hline $\begin{array}{l}\text { Hypertensive crises during } \\
\text { the last } 6 \text { months }\end{array}$ & № / Нет & 22.3 & 1.000 & \multirow[t]{2}{*}{$>0.05$} \\
\hline $\begin{array}{l}\text { Наличие гипертонического (-их) } \\
\text { криза(-ов) за последние } 6 \text { мес }\end{array}$ & Yes / Да & 26.2 & $1.233(0.953-1.595)$ & \\
\hline \multicolumn{5}{|c|}{ Factors related to the therapy / Факторы, связанные с терапией } \\
\hline $\begin{array}{l}\text { Number of antihypertensive drugs } \\
\text { used at the moment of inquiry }\end{array}$ & 1-2 drugs / 1-2 препарата & 20.3 & $2.383(1.577-3.602)$ & \multirow[t]{2}{*}{$<0.001$} \\
\hline $\begin{array}{l}\text { Количество принимаемых АГП } \\
\text { на момент опроса }\end{array}$ & 3 drugs and more / 3 препарата и более & 9.6 & 1.000 & \\
\hline $\begin{array}{l}\text { Change in hypertension treatment } \\
\text { regimen as compared with the } \\
\text { cardiology center's recommendations }\end{array}$ & No change / Нет, схема осталась той же & 14.0 & 1.000 & \multirow[t]{2}{*}{$<0.05$} \\
\hline $\begin{array}{l}\text { Произведены ли изменения схемы } \\
\text { лечения АГ по сравнениюс } \\
\text { рекомендациями кардиодиспансера }\end{array}$ & Change had been made / Да, произведены & 19.2 & $2.474(1.035-2.045)$ & \\
\hline $\begin{array}{l}\text { Use of fixed combinations at the } \\
\text { moment of inquiry }\end{array}$ & № / Нет & 18.9 & $1.43(0.988-2.07)$ & \multirow[t]{2}{*}{$<0.05$} \\
\hline $\begin{array}{l}\text { Прием фиксированных комбинаций } \\
\text { на момент опроса }\end{array}$ & Yes / Да & 13.5 & 1.000 & \\
\hline
\end{tabular}

It is usually believed that an increase in a number of received drugs is associated with reduced treatment adherence $[19,21]$. However our study has demonstrated an association between the use of 1-2 drugs with the increased possibility of irregular intake as compared with the use of 3 and more drugs $(\mathrm{OR}=2.383 ; 95 \% \mathrm{Cl}$ from 1.577 to 3.602 ; $\mathrm{p}<0.001)$. Apparently, this may be explained by un- группой пациентов с низкой приверженностью [21]. В других отечественных исследованиях больший стаж АГ также ассоциировался с повышением приверженности к терапии $[18,20]$. В то же время наличие гипертонических кризов не ассоциировалось с нерегулярным приемом АГП.

Традиционно считается, что увеличение числа принимаемых препаратов ассоциируется со снижением приверженности к терапии $[19,21]$. Однако в настоящем иссле- 
complicated hypertension of short duration in patients who were prescribed 1-2 drugs, while 3 and more drugs were prescribed for patients with CHD and longer duration of the disease. These results were received in clinical practice and may differ from the results of clinical trials and studies of selected groups of patients (for example, with short hypertension duration), in which patients have approximately similar clinical characteristics (the presence of complications, duration of the disease, etc.). Increase in a number of prescribed AHD in such patients can lead to reduced adherence. In real practice patients are rather heterogeneous and the regularity of antihypertensive treatment can be influenced by other factors while the importance of number of drugs may be less significant. At the same time, one Italian trial has revealed better treatment adherence at the prescription of several drugs even in patients with a short duration of hypertension [22].

Conspicuous is the fact of significant increase in OR of irregular antihypertensive drugs intake in patients who had changed the treatment regimen during the 6 months of follow-up ( 1.5 compared to patients without treatment regimen changes; $p<0.05$ ). On one hand, the change of a treatment scheme may indicate difficulties in hypertension control. On the other hand, this change may be a risk factor for the treatment adherence deterioration (if this change is made by a doctor) or the indicator of poor treatment adherence in general (if the treatment regimen is changed by a patient himself)

The use of fixed drug combinations was, as expected, associated with the decreased probability of irregular treatment $(\mathrm{OR}=1.43 ; 95 \% \mathrm{Cl}$ from 0.988 to $2.07 ; p<0.05$ ).

\section{Conclusion}

The formation of treatment adherence is a complex process associated with many factors and their combinations. Conducting researches that estimate compliance with doctor's recommendations allows to reveal "risk groups" for poor adherence to antihypertensive treatment - these are men (more seldom, women) with short hypertension duration and no concomitant diseases, who make little account of their hypertension and refuse drugs intake when they feel well.

Significant number of factors associated with irregular antihypertensive treatment or its refusal is controllable, but they demand special approaches or educational programs implemented by consulting physician or in the format of Health schools. довании прием 1-2 препаратов ассоциировался с увеличением шансов нерегулярного приема по сравнению с приемом 3 и более препаратов (ОШ=2,383; 95\% ДИ от $1,577$ до 3,602; $p<0,001)$. Вероятно, это обусловлено тем, что 1 - 2 препарата назначали в основном пациентам с неосложненной АГ с небольшим стажем заболевания, в то время как 3 и более препаратов назначали пациентам с ИБС и более длительным стажем заболевания. Данные результаты получены в клинической практике, поэтому они могут отличаться от результатов клинических исследований и исследований селективных групп пациентов (например, с небольшим стажем АГ) , в которых пациенты имеют примерно сходные клинические характеристики (наличие осложнений, стаж заболевания и др.) . У таких пациентов увеличение количества АГП может приводить к снижению приверженности. В реальной практике пациенты достаточно разнородны, и для формирования регулярного приема АГП важны другие факторы, а роль числа препаратов может быть менее значимой. В то же время в одном итальянском исследовании даже у пациентов с небольшим стажем АГ назначение нескольких препаратов было ассоциировано с большей приверженностью к терапии [22].

Обращает на себя внимание высокое ОШ нерегулярного приема АГТ у пациентов, которые меняли схему лечения на протяжении 6 месяцев наблюдения ( 1,5 по сравнению с пациентами у которых схема лечения не менялась, $p<0,05)$. С одной стороны, смена схемы лечения может быть маркером сложно контролируемой АГ. С другой стороны, смена схемы лечения может быть фактором риска снижения приверженности к лечению (если ее производит врач) или признаком низкой приверженности пациента к лечению в целом (если схему лечения меняет сам пациент).

Прием фиксированных комбинаций ожидаемо ассоциировался со снижением вероятности нерегулярного приема АГП (ОШ=1,43; $95 \%$ ДИ от 0,988 до 2,07; $<<0,05$ ).

\section{Заключение}

Формирование приверженности к лечению - это сложный процесс, ассоциированный с множеством факторов и их сочетаний. Проведение исследований по оценке соблюдения врачебных рекомендаций в динамике позволяет установить «группы риска» низкой приверженности к АГТ или ее нерегулярного приема - это мужчины (в меньшей степени женщины) с небольшим стажем АГ и отсутствием сопутствующих заболеваний, которые не придают большого значения имеющейся у них АГ, и при хорошем самочувствии отказываются от приема препаратов.

Значительная часть факторов, ассоциированных с нерегулярным приемом АГП или отказом от нее, являются управляемыми, но требующими применения специальных подходов/реализации образовательных технологий либо лечащим врачом, либо в формате Школ здоровья. 


\section{References / Литература}

1. Kolandaivelu K, Leiden BB, O'Gara PT, et al. Non-adherence to cardiovascular medications. Eur Heart J 2014;35:3267-76.

2. Alhalaiqa F, Deane KH, Nawafleh AH, et al. Adherence therapy for medication non-compliant patients with hypertension: a randomised controlled trial. J Hum Hypertens 2012;26(2):117-26.

3. Koziolova N.A., Shatunova I.M., Lazarev I.A. Prevalence and particularities of left ventricle hypertrophy in hypertensive patients with high treatment adherence. Arterial'naya Gipertenziya 2011;17(5):4549. Russian (Козиолова Н.А., Шатунова И.М., Лазарев И.А. Частота и особенности развития гипертрофии левого желудочка у больных гипертонической болезнью при высокой приверженности к лечению. Артериальная Гипертензия 2011;17(5):454-9).

4. Corrao G, Parodi A, Nicotra F, et al. Better compliance to antihypertensive medications reduces cardiovascular risk. J Hypertens 2011;29:610-8

5. Maronde RF, Chan LS, Larcen FJ, et al. Underutilization of antihypertensive drugs and associated hospitalization. Med Care 1989;27:1159-66.

6. Oganov R.G., Timofeeva T.N., Koltunov I.E. et.al. Epidemiology of arterial hypertension in Russia. 20032010 Federal monitoring results. Kardiovaskulyarnaya Terapiya i Profilaktika 2011;10(1):9-13. Russian (Оганов Р.Г., Тимофеева Т.Н., Колтунов И.Е. и др. Эпидемиология артериальной гипертонии в России. Результаты федерального мониторинга 2003-2010 гг. Кардиоваскулярная Терапия и Профилактика 2011;10(1):9-13)

7. Boitsov S.A., Balanova lu.A., Shalnova S.A. et al. Hypertension in persons of 25-64 years old: prevalence, awareness, treatment and control. By the ESSE study materials. Kardiovaskulyarnaya Terapiya i Profilaktika 2014;14(4):4-14. Russian (Бойцов С.А., Баланова Ю.А., Шальнова С.А. и др. Артериальная гипертония среди лиц 25-64 лет: распространенность, осведомленность, лечение и контроль. По материалам исследования ЭССЕ. Кардиоваскулярная Терапия и Профилактика 2014;14(4); 4-14)

8. Leonova M.V., Belousov lu.B., Shteinberg L.L. et al. Pharmacoepidemiology of arterial hypertension in Russia (by the PIFAGOR III pharmacoepidemiological study results). Rossiyskiy Kardiologicheskiy Zhurnal 2011;2(88):9-16. Russian (Леонова М.В., Белоусов Ю.Б., Штейнберг Л.Л. и др. Фармакоэпидемиология артериальной гипертонии в России (по результатам фармакоэпидемиологического исследования ПИФАГОР ІІІ). Российский Кардиологический Журнал 2011; 2 (88):9-16).

9. Koncevaya A.V., Romanenko T.S., Vygodin V.A. et al. Antihypertensive treatment pharmacoepidemiology and efficacy in real practice of a specialized cardiologic center. Ration Pharmacother Cardiol 2015;11 (1):8-17. Russian (Концевая А.В., Романенко Т.С., Выгодин В.А. и др. Фармакоэпидемиология и эффективность антигипертензивной терапии в реальной практике специализированного кардиологического учреждения. Рациональная Фармакотерапия в Кардиологии 2015;11(1):8-17).

10. Fitz-Simon N, Bennett K, Feely J.A review of studies of adherence with antihypertensive drugs using prescription databases. Ther Clin Risk Manag 2005;1 (2):93-106.

11. Bobrow K., Brennan T., Springer D. Efficacy of a text messaging (SMS) based intervention for adults with hypertension: protocol for the StAR (SMS Text-message Adherence support trial) randomised controlled trial. BMC Public Health 2014;14(1):28.

12. Burke TA, Sturkenboom MC, Lu SE, et al. Discontinuation of antihypertensive drugs among newly diagnosed hypertensive patients in UK general practice. J Hypertens 2006;24(6):1193-200.
13. Shalnova S.A., Deev A.D. Vihireva O.V. on behalf of the researchers. Arterial hypertension as viewed by outpatients. The first results of the GARANT study. Kardiovaskulyarnaya Terapiya i Profilaktika 2007;6(5):30-3. Russian (Шальнова С.А., Деев А.Д., Вихирева О.В. от имени исследователей. Артериальная гипертония глазами амбулаторных пациентов. Первые результаты исследования ГАРАНТ. Кардиоваскулярная Терапия и Профилактика 2007;6(5):30-3).

14. Konobeeva E.V., Svartz lu.G., Korsunova E.N. et al. Possibilities of increase in deliberate motivation in patients of heart profile. Implementation of standard graphic recommendations. Fundamental'nye Issledovaniya 2013;9 part 1:58-61. Russian (Конобеева Е.В., Шварц Ю.Г., Корсунова Е.Н. и др. Возможности повышения осознанной мотивации пациентов кардиологического профиля. Использование стандартных наглядных рекомендаций. Фундаментальные Исследования 2013;9 часть 1:58-61).

15. Improving adherence in cardiovascular care. A toolkit for health professionals. National Heart Foundation of Australia. Available at: http://www.heartfoundation.org.au/SiteCollectionDocuments/Improving-adherence-in-cardiovascular-care-toolkit.pdf. Accessed by 16.05.2015.

16. Wong MC, Jiang JY, Griffiths SM. Factors associated with antihypertensive drug compliance in 83,884 Chinese patients: a cohort study. J Epidemiol Community Health 2010;64(10):895-901.

17. Dessie A, Asres $G$, Meseret $S$, et al. Adherence to antihypertensive treatment and associated factors among patients on follow up at University of Gondar Hospital, Northwest Ethiopia. BMC Public Health 2012;12(1):282

18. Chohlov A.L., Lisenkova L.A., Rakov A.A. Analysis of factors determining adherence to antihypertensive treatment. Kachestvennaya Klinicheskaya Praktika 2003;4:59-66. Russian (Хохлов А.Л., Лисенкова Л.А., Раков А.А. Анализ факторов, определяющих приверженность к антигипертензивной терапии. Качественная Клиническая Практика 2003;4:59-66).

19. Monane M, Bohn RL, Gurwitz JH, et al. The effects of initial drug choice and comorbidity on antihypertensive therapy compliance: results from a population-based study in the elderly. Am J Hypertens 1997:10:697-704.

20. Oganov R.G., Pogosova G.V., Koltunov I.E. et.al. Regular treatment and prevention - key to improvement of a situation with cardiovascular diseases in Russia: results of the Russian multicenter study - RELIF part Il. Kardiologiia 2007;1 1:30-9. Russian (Оганов Р.Г., Погосова Г.В., Колтунов И.Е. и др. РЕЛИФ - РЕгулярное Лечение И проФилактика - ключ к улучшению ситуации с сердечно-сосудистыми заболеваниями в России: результаты российского многоцентрового исследования (часть ІІ). Кардиология 2007;11:30-9).

21. Fofanova T.V., Ageev F.T. Kadushina E.B. et al. Psychosomatic aspects of low adherence to antihypertensive medical treatment. Sistemnye Gipertenzii 2014; 11(3):11-6. Russian (Фофанова Т.В., Агеев Ф.Т., Кадушина Е.Б. и др. Психосоматические аспекты низкой приверженности больных артериальной гипертонией медикаментозной терапии. Системные Гипертензии 2014; 11(3):11-6).

22. Mazzaglia G, Ambrosioni E, Alacqua M, et al. Adherence to antihypertensive medications and cardiovascular morbidity among newly diagnosed hypertensive patients. Circulation 2009;120(16):1598605

Received / Поступила: 04.05.2015 Accepted / Принята в печать: 25.05.2015 